\title{
An Archaeological and Historical Survey of Stinson Municipal Airport in Bexar County, Texas
}

I. Waynne Cox

Anne A. Fox

David Hafernick

Kelly Scott

Follow this and additional works at: https://scholarworks.sfasu.edu/ita

Part of the American Material Culture Commons, Archaeological Anthropology Commons, Environmental Studies Commons, Other American Studies Commons, Other Arts and Humanities Commons, Other History of Art, Architecture, and Archaeology Commons, and the United States History Commons

Tell us how this article helped you.

This Article is brought to you for free and open access by the Center for Regional Heritage Research at SFA ScholarWorks. It has been accepted for inclusion in Index of Texas Archaeology: Open Access Gray Literature from the Lone Star State by an authorized editor of SFA ScholarWorks. For more information, please contact cdsscholarworks@sfasu.edu. 


\section{An Archaeological and Historical Survey of Stinson Municipal Airport in Bexar County, Texas}

\section{Creative Commons License}

\section{(c) (1) \&}

This work is licensed under a Creative Commons Attribution-NonCommercial 4.0 International License 


\section{AN ARCHAEOLOGICAL AND HISTORICAL SURVEY OF STINSON MUNICIPAL AIRPORT IN BEXAR COUNTY, TEXAS}

I. Waynne Cox, Anne A. Fox, David Hafernik, and Kelly Scott

Center for Archaeological Research

The University of Texas at San Antonio Archaeological Survey Report, No. 178 





\section{AN ARCHAEOLOGICAL AND HISTORICAL SURVEY OF STINSON MUNICIPAL AIRPORT IN BEXAR COUNTY, TEXAS}

I. Waynne Cox, Anne A. Fox, David Hafernik, and Kelly Scott

Texas Antiquities Committee Permit No. 674

Center for Archaeological Research

The University of Texas at San Antonio ${ }^{\circledR}$

Archaeological Survey Report, No. 178 
The following information is provided in accordance with General Rules of Practice and Procedure Chapter 41.11 (Investigation Reports), Texas Antiquities Committee:

1. Type of investigation: archaeological survey and historical research at Stinson Municipal Airport;

2. Project name: TransPlan/Stinson Field Archaeological Survey;

3. County: Bexar County, Texas;

4. Principal investigator: Jack D. Eaton; coprincipal investigator: Anne A. Fox;

5. Name and location of sponsoring agency: TransPlan, New York;

6. Texas Antiquities Committee Permit No. 674;

7. Published by the Center for Archaeological Research, The University of Texas at San Antonio, San Antonio, Texas 78285-0658, 1989.

A list of publications offered by the Center for Archaeological Research can be obtained by sending $\$ 1.00$ to the Center for Archaeological Research, The University of Texas at San Antonio, San Antonio, Texas 78285-0658. 


\begin{abstract}
In February 1988, the Center for Archaeological Research at The University of Texas at San Antonio conducted an archaeological survey and archival and historical research for the Stinson Municipal Airport in south Bexar County, Texas, under contract with TransPlan. No prehistoric or historic archaeological sites were found. However, a historic cemetery on the grounds of the airport was surveyed, and its approximate visible limits were recorded. It is recommended that further work be done to completely delineate the cemetery's boundaries before expansion of the airport is planned.
\end{abstract}




\section{TABLE OF CONTENTS}

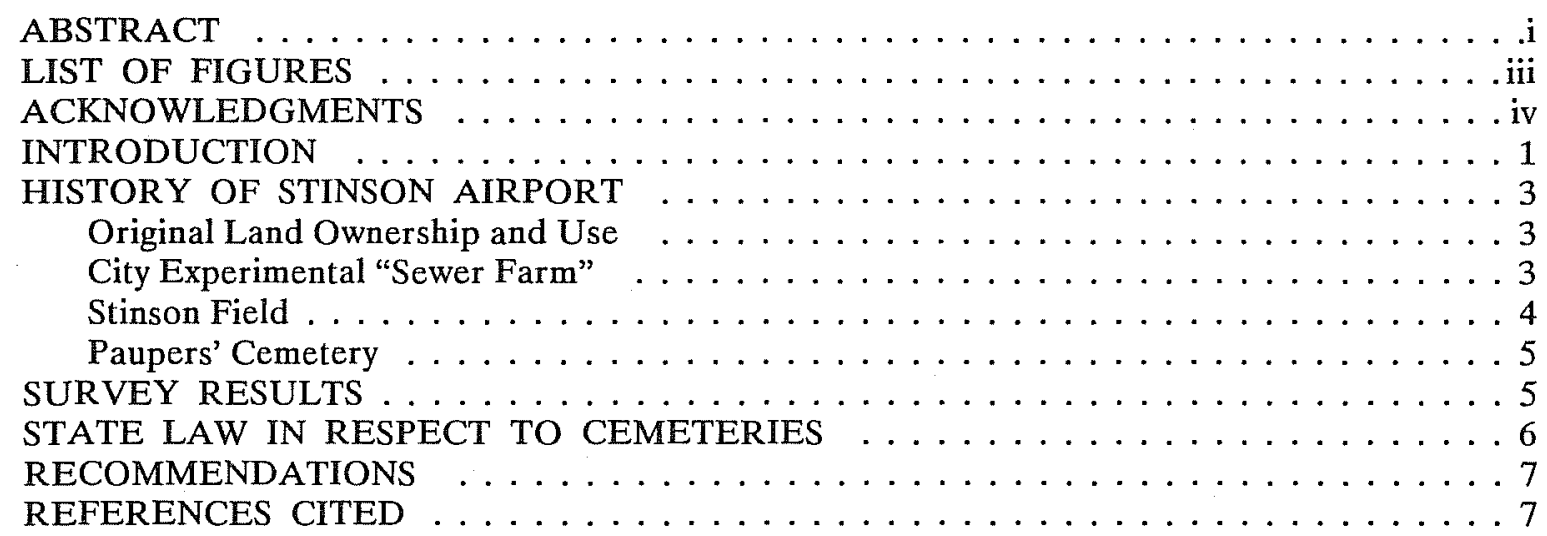




\section{LIST OF FIGURES}

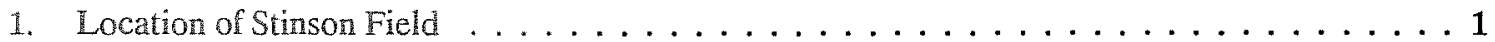

2. Project Area . . . . . . . . . . . . . . . . . . . . 2

3. Location of Paupers' Cemetery in Respect to Present Runways . . . . . . . . . . 6 


\section{ACKNOWLEDGMENTS}

The authors would like to take this opportunity to thank the many individuals who were so kind as to assist us in obtaining the information for this report. We are indebted to Art Wendt, director of Stinson Municipal Airport, and his secretary, Flo Mogan, for their information and their help in gaining access to the area. Thanks also to Charles Stevens of Startzville, Texas, John Delgado of Angelus Funeral Home, and Glenn Matlock of Porter Loring Funeral Home for their information on funeral practices and records. Larry Alvarez of San José Cemetery provided invaluable information concerning the paupers' cemetery. Sgt. O'Donohue of the Kelly Air Force Base Historical Office and John Mancuso of the Fort Sam Houston Military Museum kindly searched their files for the military history. Father Roman, pastor of Espada Church, and Brother Edward Loch, archivist of the Catholic Chancery, were also helpful. As ever, John Ogden Leal, Bexar County archivist, was most helpful. Finally, our gratitude to Scott Highley of the City Public Health Department for providing us with the key information that allowed us to put the pieces together. 


\section{INTRODUCTION}

In February 1988, the Center for Archaeological Research (CAR) at The University of Texas at San Antonio (UTSA) was requested by TransPlan to conduct archival and historical research and an archaeological survey of a section of Stinson Municipal Airport, including an area extending south of the airport as far as Loop 410, in south Bexar County, Texas. The study was conducted in connection with the preparation of an Environmental Impact Statement being prepared for planned future development of the airport. The purpose of the study was to determine if the proposed development would impact any cultural resources in the area. Texas Antiquities Committee Permit No. 674 was issued for the project.

The area involved in the project is located within the Mission Parkway National Register District. Stinson Field and any structures related to its history prior to World War II are contributing elements of that district. The Federal Aviation Administration (FAA) will need to consider the effects of the proposed action on them, in accordance with Section 106 of the National Historic Preservation Act.

The Mission Parkway National Register District also includes as contributing elements, four Spanish missions, of which Mission San Juan Capistrano is located a short distance south of Stinson Airport. Mission San Juan Capistrano is also a registered Texas Historic Landmark, a State Archeological Landmark, and is listed individually on the National Register of Historic Places. The FAA needs to take into account any adverse effects from increased noise levels of additional air traffic on this important resource, and to allow for comments of the State Historic Preservation Officer and the Advisory Council on Historic Preservation.

Stinson Municipal Airport is located approximately six miles south of the center of the city of San Antonio (Fig. 1). It is bounded on the west by U.S. Highway 281, on the north by Cadmus Road, on the east by Mission Road, and on the south by Ashley Road (Fig. 2). The area to be acquired for future expansion is located directly to the south of the airport between Ashley Road and Southwest Loop 410. Directly north of the airport are two city cemeteries, the San José Cemetery and Mission Burial Park. Mission San Juan
Capistrano and the Mission Road Foundation School are located to the east and southeast of the airport, respectively.

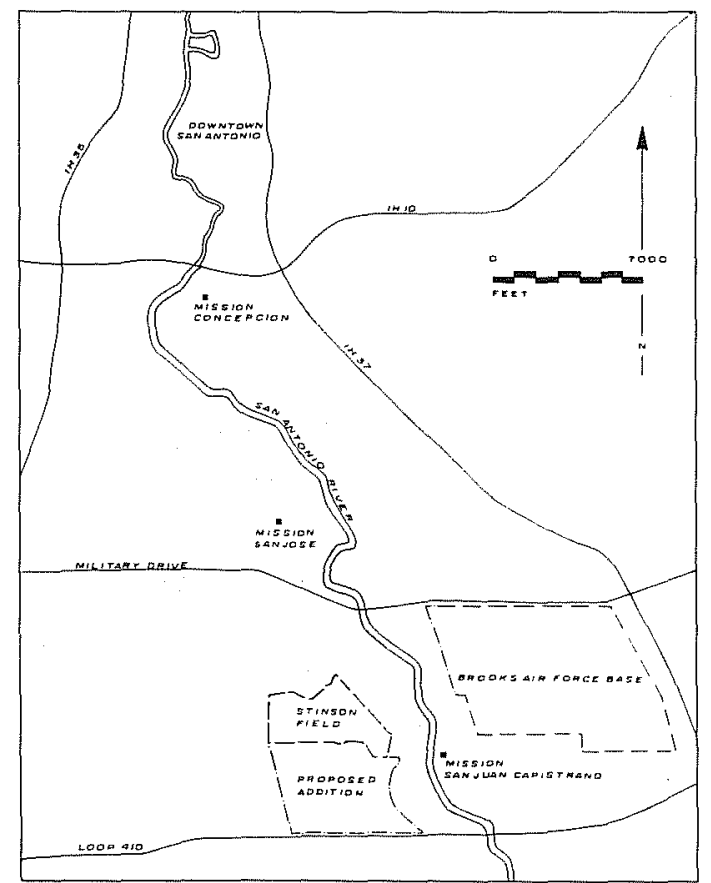

Figure 1. Location of Stinson Field.

The airport property is relatively flat, except where Sixmile Creek runs west to east across the southern section. Elevation of the airport is 570 feet above mean sea level (MSL). The land to the south of Sixmile Creek rises slowly to a maximum elevation of 580 feet above MSL near Loop 410. Except for the cleared area around the airport facilities and a few cultivated fields south of AshleyRoad, most of the property is covered with wild grasses and mesquite thickets. There are a few small houses along Ashley Road, and a few more houses are on a gravel road running parallel to Ashley Road.

Previous archaeological work in the general area, other than numerous projects at the Spanish missions, has consisted of surveys in connection with the City of San Antonio's 201 Wastewater Treatment Project (Fox 1977; Fox, McGraw, and Valdez 1978) and the Mission Parkway (Scurlock et al. 1976). The Mission Parkway survey recorded two possible sites within or near the vicinity of this project (Scurlock et al. 1976:142). 


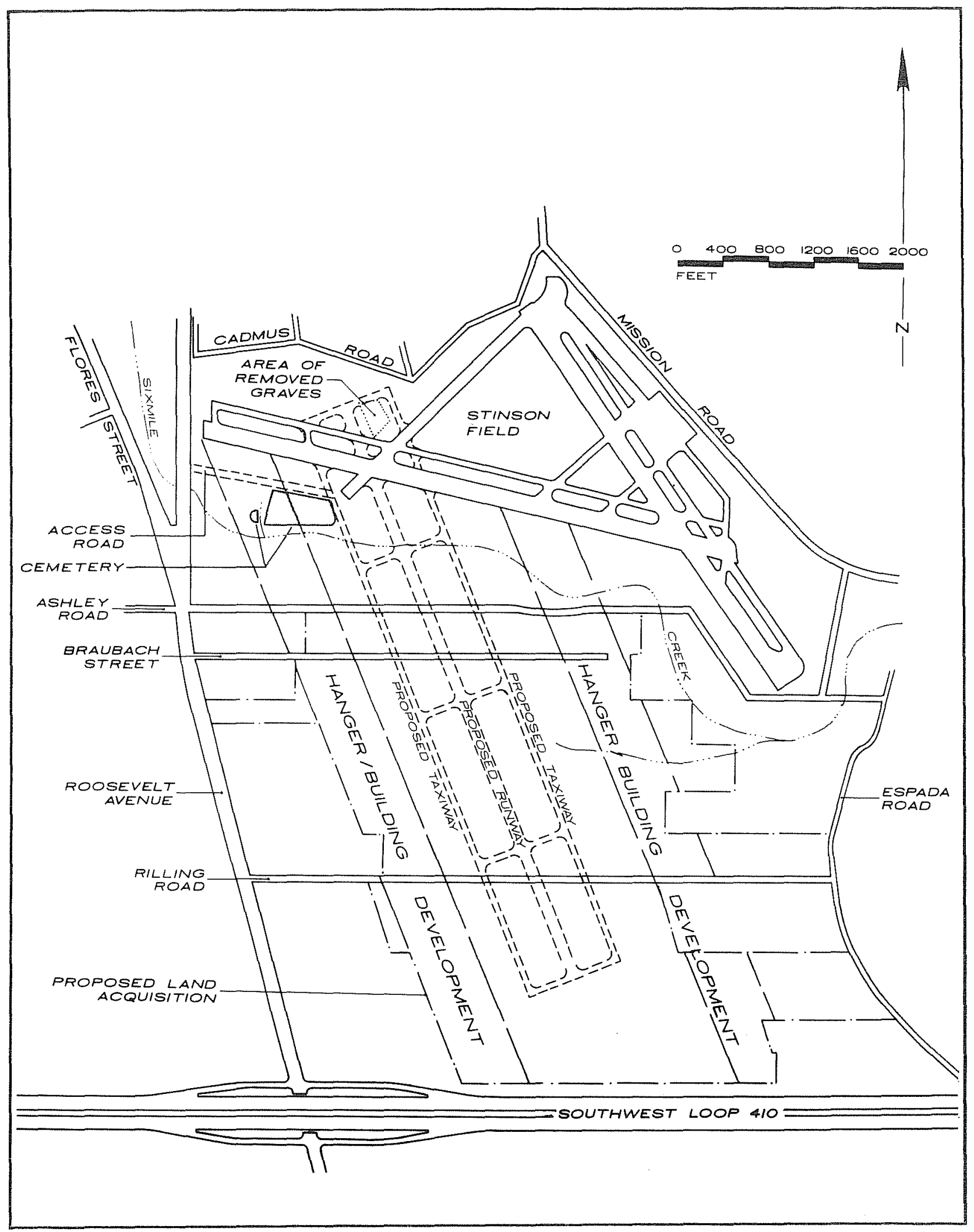

Figure 2. Project Area. 
A prehistoric aboriginal site, MP-62, was reported by local informants to be somewhere in the vicinity of the Ashley Road crossing of Piedras Creek. The area was surveyed twice (on one occasion the survey party included Anne Fox), and no trace of such a site was found. Since the location, or indeed the existence, of the site could not be confirmed, it was not included on the project map. The other site, MP-63, was the location of a 1927 plane crash "about a quarter of a mile from U.S. Highway 281." Since no trace of the crash was visible in 1976 and none is visible today, an exact location could not be determined, and the site was not included on the project map.

\section{HISTORY OF STINSON AIRPORT}

\section{ORIGINAL LAND OWNERSHIP AND USE}

In September 1837, Manuel Leal conveyed his headright of a league and one labor, to which he was entitled as a "native resident of the Republic of Texas," to William P. Delmour for a payment of $\$ 600$. This allowed Delmour the right "to select such location for said land as he may deem best" (BCDR Vol. D1:137). Delmour, city secretary and clerk of the Board of Land Commissioners for Bexar County in 1838 , selected a site some five miles south of the city below Mission San José on the west bank of the San Antonio River (Corner 1890:149; BCDR Vol. F2:55, Vol. E1:21; County Survey Book A). This 4605.5-acre tract extended from Mission San José y San Miguel de Aguayo to just north of Mission San Juan Capistrano, and west to what is now Pleasanton Road (Giraud 1874).

In June 1847, the estate of the deceased Delmour sold one-half of the league to David C. Vanderlip for $\$ 738$ (BCDR Vol. F2:55). Vanderlip, in turn, conveyed the one-half league to Rodrick Thomas Higginbotham for $\$ 807$ in September 1850. Higginbotham, wounded in the "Council House fight" on March 19, 1840, went on to serve in both the war for Texas independence and the Mexican War (Barnes 1910:239).

In 1855, Higginbotham sold 685.20 acres of the tract, containing the land under investigation, to Aurelius E. Edgeworth for $\$ 2397.50$ (BCDR Vol.
P1:289). Three years later Aurelius and Susan Edgeworth mortgaged the property to Charles L. Pyron for $\$ 317$ after they had defaulted on a loan in July 1868; Pyron auctioned the tract to the highest bidders. John $\mathrm{E}$. Mitchell and William McLane received the property for $\$ 425$ ( $B C D R$ Vol. U1:496). In 1870, McLane traded the acreage for $\$ 1$ and 35 shares of the San Antonio Meat Extract Company; the directors of this company were A. F. Wulff, C. E. Elmendorf, Dr. Theodore Hertzberg, A. Sieming, H. Klocke, and E. Pentenrieder (BCDR Vol. V1:411). In 1880, the company sold the property to Feargus O.C. Robinson, a resident of Devon, England, for $\$ 900$ $(B C D R$ Vol. 16:150). He, in turn, conveyed the property, through his attorney Frank P. Hord, to L. S. Berg and J. Herman Schultze in 1890 (BCDR Vol. 72:80).

\section{CITY EXPERIMENTAL "SEWER FARM"}

In the late 1890 s, the city began the installation of its sanitary sewer system. In 1895, the city purchased 535 acres from L. S. Berg and Herman Schultze, at a total price of $\$ 18,971.36$, to be used as a waste disposal area ( $B C D R$ Vol. 145:278, Vol. 154:25). It was suggested by the city council that additional revenue could be acquired by leasing the land and irrigation as a "sewer farm" (CCM Vol. M, January 3, 1897). After lengthy discussion on how to lease the farm, Mayor Bryan Callaghan "was authorized to advertise for bids for renting the entire farm for two years" (CCM Vol. M, March 7, 1898). Casper J. Rigelsteir was the highest bidder with $\$ 600$ for the first year and $\$ 750$ per year for additional years (CCM Vol. M, March 14, 1898). By 1899, the lease had been transferred to R. W. Hamilton and Company, who applied for an extension of the lease to March 1, 1904, at an increase in price of $\$ 1000$ per year (CCM Vol. $\mathrm{M}$, February 20, 1899). However, in September 1901, Alderman Seidel (CCM Vol. O, September 9, 1901) introduced a resolution:

Be it resolved by the city council of the city of San Antonio, that after a thorough investigation of the conditions surrounding the present "sewer farm," we are of the opinion that it would be for the interest of the city of San Antonio to 
discontinue the use of said farm as a sewer farm at the earliest practical date, and this city council pledges itself to every effort to that end. On motion same was unanimously adopted.

Thus ended the city's experimental sewer farm; however, as late as 1916 the U. S. Army held a lease for 50 acres to use as an experimental sewer farm (San Antonio Express 1916).

In December 1915, the city council (CCM Vol. A, December 23, 1915) proposed that:

Several acres of the 'sewer farm' be deeded to the Catholic Church for cemetery purposes, in exchange for land to be used by the city for sewer right-of-way. The mayor appointed one appraiser for the city, the Church one, and the two selected a third to determine the manner of exchange.

\section{STINSON FLELD}

In 1914, a young woman arrived in San Antonio who was to have a major impact on the future of aviation. Katherine Stinson obtained permission to fly from the facilities of Fort Sam Houston. Katherine had become the fourth licensed woman pilot in 1912, and at age 16, she was the youngest. Two years later her younger sister, Marjorie, took that title from her by graduating from the Wright Flying School. Their brother, Edward (Eddie), joined them in 1915 (Parmelee 1972:4). Together they formed the Stinson School of Aviation.

This was not, however, San Antonio's first exposure to aviation. In 1909 , the U.S. Government selected an open area adjacent to the Quadrangle of Fort Sam Houston as the site for a flight training center. Lt. Benjamin Foulois, nine enlisted men, and 17 crates of airplane parts arrived in February 1910. He made his maiden flight in the Wright S. C. No. 1 on March 2 (Bilstein and Miller 1985:17). By early 1911, Foulois and his crew were augmented by the addition of a new Curtiss Model D aircraft and three additional pilots, Lt. Paul Beck, Lt. John Walker, and Lt. George Kelly. In May 1911, Lt. Kelly was killed in a crash near the camping area of Fort Sam
Houston. The site of the accident, in the middle of the reservation with its thousands of troops, prompted the commander, General William Carter, to immediately curtail all flying activity at the post, and the fledging Signal Corps was removed to College Park, Maryland (ibid.:18). The First Aero Squadron returned to Fort Sam Houston in 1914, however, this time to undertake operations at Remount Station No. 2, some four miles to the north (Bilstein and Miller 1985:19).

On December 17, 1915, Eddie Stinson made the first flight from Fort Sam Houston to the location of the new home for the Stinson School of Aviation, on the old sewer farm south of the city. He circled the new field several times, reaching a height of 7000 feet before landing (San Antonio Express 1915a). The students of instructors Katherine, Marjorie, and Eddie Stinson consisted of 10 men from Dayton, Ohio (San Antonio Express $1915 b)$.

The formal lease of Stinson Field was approved by the city on January 20,1916, providing that the city "... reserve enough ground for burial purposes, and the government to keep that portion it now has without being molested by flyers. The price agreed upon being $\$ 5.00$ per year" (CCM Vol. A, January 20, 1916).

The flight school, although extremely successful, was short-lived. By August 1, 1917, attrition from accidents had reduced their fleet of airplanes to two flyable trainers. The two remaining ships, a Wright and an O-X Burgess, soon were wrecked, and the assets of the school were liquidated (Underwood 1969:10). The airport continued to serve the public as "Stinson Field" until October 15, 1927, when a newspaper reporter named Bill Winburn and four others died in an aircraft accident at the field, and the name changed to Winburn Field (San Antonio Express and News 1965). It was so named when the first scheduled airmail flight arrived on February 6, 1928. The airfield was renamed in honor of its founders on July 15, 1936. In 1935, Braniff Airways began commercial flights into Stinson Field, followed in 1939 by Eastern Airlines.

The Army Air Force acquired Stinson Field in October 1942 as an auxiliary of Kelly Air Field and retained it throughout World War II. It reverted to the city in 1946 (Scurlock et al. 1976:144). Because of the growth of aviation in San Antonio, the city acquired 1200 acres to the north of the city for a new airport, what was to become San Antonio International Airport (San Antonio Express and News 1965). 


\section{PAUPERS' CEMETERY}

Apparently in 1915 the city council's negotiations with the Catholic church did not prove productive, and the city retained title to the area reserved for burials. At some point it became the paupers' cemetery for the city. The exact area reserved has not yet been determined and could have included any of the remaining 485 acres not leased to the army.

The pauper burials were arranged through the city's San José Cemetery at 8235 Mission Road, but the burial records were maintained by the various funeral homes contracting with the city for pauper burials (L. Alvarez, personal communication). Therefore, the exact number and locations of plots cannot be determined at this time. Some 20 graves retain information about the identity of the deceased, but there is evidence for at least 400 interments, with a probability of many more. The cemetery was probably in use until the field was leased to the War Department in July 1941.

The Southton USGS quadrangle map of the area, done in 1967, indicates an additional cemetery area to the north of the east-west runway of the airport. Art Wendt, airport director, reports that these burials were removed in connection with the construction of a taxiway north of the runway. It appears likely that these graves may have been a part of the original paupers' cemetery, which would indicate that the cemetery was once a great deal larger than the area now protected by tall grass and mesquite brush.

\section{SURVEY RESULTS}

On March 3, 1988, personnel from the CARUTSA conducted a pedestrian survey of an area for the proposed expansion of Stinson Airport. The purpose of the survey was to determine the presence of any historic or prehistoric remains that would be affected by the proposed runway construction. The survey crew consisted of Waynne Cox, research associate; David Hafernik and Kelly Scott, technical staff assistants; and three students from UTSA: Barry Nowlin, Chad Webster, and Mike Zibelin. All field notes, photographs, and drawings pertaining to this project are on file at the CAR-UTSA.
The survey area between Rilling Road and Southwest Loop 410 has been badly disturbed by the construction and landscaping of the Rilling Road Sewage Treatment Plant. This area was therefore not intensively examined.

The ground survey consisted of walking transects over the approximately 230 acres that have been designated for the proposed runway. The first phase of the survey consisted of an area south of Stinson Airport between Rilling Road and Ashley Road and between Roosevelt Road (U.S. Highway 281) and Espada Road (Fig. 2). This area is almost completely flat, with little variation in terrain or vegetation. Once plowed fields, the area is now overgrown with mesquite and native grasses. No indication of historic human habitation was found, other than the houses at the western edge of the survey area. No indication of prehistoric occupation was found. The survey was somewhat impaired by grass cover and trash dumping.

The second phase of the survey involved the area north of Ashley Road on the Stinson Airport property. Sections of this land have been cleared and are now maintained by Stinson Airport; the other areas are vegetated with heavy secondary growth. The main topographic feature of this area is Sixmile Creek, which has been channelized through the western two-thirds of the property. The only evidence of historic activity was a cemetery with approximately 400 visible graves located in a brushy area north of the creek (Fig. 3). An overview of the history of this cemetery has been presented in the previous section. No other historic or prehistoric sites were located during the survey.

Although the crew went into the field fully prepared to do shovel testing, no occasion was found to justify such examination. The flat, open areas to the south of the air field had been plowed for many years and showed no indication of occupation or other use. The creek banks were composed primarily of fill, and the channel had apparently been straightened, indicating that such testing would be a waste of time and effort. 


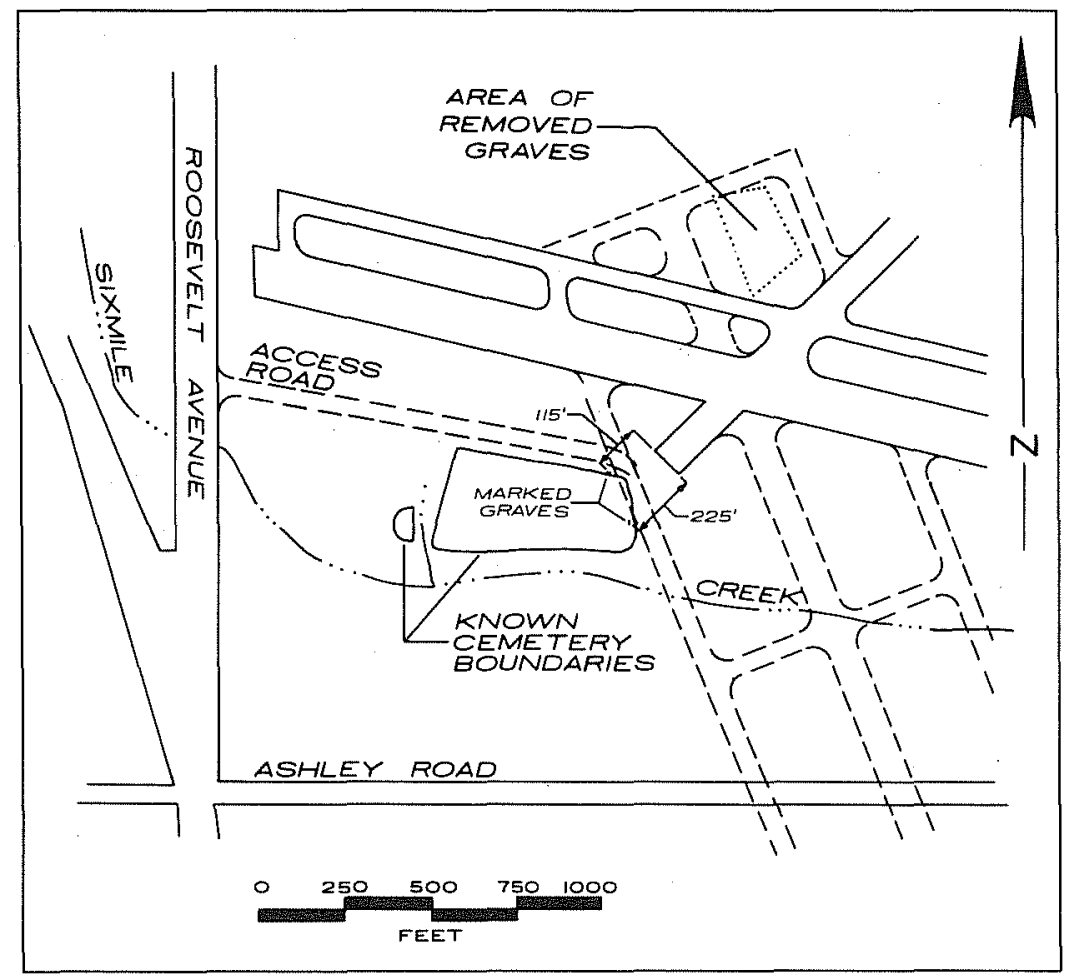

Figure 3. Location of Paupers' Cemetery in Respect to Present Runways.

\section{STATE LAW IN RESPECT TO CEMETERIES}

After a cursory examination of Vernon's Annotated Revised Civil Statutes of the State of Texas (1964:381-415) concerning cemeteries, the following quotations may be of interest as they affect old cemeteries no longer in use for interment. Naturally, this is merely intended as background information and should not be considered in any way a legal opinion.

Article 912a-11. Dedication supreme until removed by Court.

[Land dedicated as a cemetery] shall be held and used exclusively for cemetery purposes, unless and until the dedication shall be removed by an order and decree of the district Court of the county in which the same is situated, in a proceeding brought therefor by the governing body of the city ... no railroad, street, road, alley, pipe line, telephone, telegraph, or electric line, or other public utility or thoroughfare whatsoever shall ever be laid out through, over, or across any part thereof, without the consent of the directors of the cemetery association owning or operating the same, or of not less than two-thirds of the owners of burial plots therein ... (Vemon's Annotated Revised Civil Statutes of the State of Texas 1964:396-397). 
Article 912a-22. Removals.

The remains of a deceased person interred in a plot in a cemetery may be removed therefrom with the consent of the cemetery association and the written consent of the surviving wife or husband, or if there is no surviving husband or wife, then of the children; or if there is no surviving husband or wife nor children, then' of the parents of the deceased, or should there be no surviving husband or wife nor children nor parent, then of the brothers and/or sisters of the deceased. If the consent of any such person or of the association cannot be obtained, permission by the county court of the county where the cemetery is situated shall be sufficient.... This provision shall not apply to or prohibit the removal of any remains from one plot to another in the same cemetery . . . (Vemon's Annotated Revised Civil Statutes of the State of Texas 1964:409-410).

\section{RECOMMENDATIONS}

No indications of prehistoric occupation were found during this survey. This may be partially blamed on heavy ground cover that made surveying difficult in many areas. Despite local informants' reports of a possible prehistoric site slightly downstream of the survey area at the Ashley Road crossing of Sixmile Creek, the Mission Parkway survey crew was unable to find it (Scurlocket al. 1976:142). It may be that periodic flooding of the creek has all but eliminated any prehistoric sites along its banks that have not been disturbed or buried by construction or channelization. Therefore, no recommendations are in order for nomination of sites to the National Register or as State Archeological Landmarks.

The cemetery has been registered with the Texas Archeological Research Laboratory in Austin as site $41 \mathrm{BX} 594$. We also urge that the FAA conduct background investigations to determine to the fullest extent possible the names of persons buried there, the number of burials, and the extent of the area of interment.
It seems likely that the paupers' cemetery may extend some distance beyond the brushy area along the north bank of the creek, both to the north and to the east. The original extent of the paupers' cemetery is difficult to determine from surface examination. The fact that burials were removed from an area north of the present eastwest runway suggests that it extends at least that far north, and may partly underlie the runway. We therefore recommend a thorough examination of the entire area to be impacted by any proposed development north of Sixmile Creek. Based on our experience in excavating historic cemeteries in connection with their removal (Fox 1984; Taylor, Fox, and Cox 1986), where there are no headstones or other grave markings, we suggest blading the entire area to be affected to remove the topsoil layer and reveal the outlines of grave pits. This should be done only under the direct supervision of a professional archaeologist with experience in this sort of work. Based on the information obtained from such examination, a plan for mitigation of the cemetery could then be formulated. Any future construction on the air field should include archaeological investigations to determine the extent of the cemetery and the subsequent removal (to another cemetery) of any burials that will be impacted by construction.

\section{REFERENCES CITED}

Barnes, C. M.

1910 Combats and Conquests of Immortal Heroes. Guessaz and Ferlet Company, San Antonio, Texas.

Bexar County, Texas

Bexar County Archives (BCA)

County Survey Book A. Bexar County Courthouse, San Antonio, Texas.

Bexar County Deed Records (BCDR) Office of the County Clerk, Bexar County Courthouse, San Antonio, Texas.

Bilstein, R. and J. Miller

1985 Aviation in Texas. Texas Monthly Press, Austin, Texas. 
City Council Minutes (CCM)

Office of the City Clerk, City Hall, San

Antonio, Texas.

Corner, W.

1890 San Antonio de Bexar, A Guide and History. Bainbridge and Corner, San Antonio, Texas.

Fox, A. A.

1977 An Archaeological Assessment of the San Antonio 201 Wastewater Treatment Project. Center for Archaeological Research, The University of Texas at San Antonio, Archaeological Survey Repont 41.

1984 A Study of Five Historic Cemeteries at Choke Canyon Reservoir, Live Oak and McMullen Counties, Texas. Center for Archaeological Research, The University of Texas at San Antonio, Choke Canyon Series 9.

Fox, A. A., A. J. McGraw, and F. Valdez, Jr.

1978 Archaeological Survey and Testing of Pipelines and Confluence Site, San Antonio 201 Wastewater Treatment Project. Center for Archaeological Research, The University of Texas at San Antonio, Archaeological Survey Report 66.

Giraud, F.

1874 Map Showing the Names of the Original Claimants to the Irrigable Lands Comprised in the Labores of the Missions of Concepción, San José, San Juan, and Espada. ... Copy on file at the Center for Archaeological Research, The University of Texas at San Antonio.

Parmelee, D.

1972 The Flying Stinson Family. The Austin Texas Star, July 9.
San Antonio Express

1915a School of Flying Has New Quarters. December 18.

1915b Texas Weather is Magnet to Flying Men of Cold East. December 19.

1916 Field Suits the Aviators. January 19.

San Antonio Express and News

1965 Aviation History in San Antonio Colorful. October 3.

Scurlock, D. Jr., A. Benavides, Jr., D. Isham, and J. W. Clark, Jr.

1976 An Archeological and Historical Survey of the Proposed Mission Parkway, San Antonio, Texas. Texas Historical Commission, Austin, Texas.

Taylor, A. J., A. A. Fox, and I. W. Cox

1986 Archaeological Investigations at Morgan Chapel Cemetery (41 BP 200), A Historic Cemetery in Bastrop County, Texas. Center for Archaeological Research, The University of Texas at San Antonio, Archaeological Survey Report 146.

Underwood, J. W.

1969 The Stinsons. Heritage Press, Glendale, California.

Vernon's Annotated Revised Civil Statutes of the State of Texas

1964 Title 26 - Cemeteries. Volume 2. Vernon Law Book Company, Kansas City, Missouri. 